\title{
HAEMOLYTIC COMPLEMENT LEVEL AND RAGOCYTE (R A CELL) CONCENTRATION IN SYNOVIAL FLUID
}

\author{
BY \\ ANDRÉ P. PELTIER, FLORIAND DELBARRE, AND G. KRASSININE \\ Clinique Rhumatologique et Centre de Recherches sur les Maladies Ostéo-articulaires (I.N.S.E.R.M.), Paris*
}

The presence of ragocytes ( $R$ A cells) (Delbarre, Kahan, Amor, and Krassinine, 1966; Hollander, McCarty, Astorga, and Castro-Murillo, 1965) and the relatively low levels of haemolytic complement (Hedberg, 1963, 1964; Pekin and Zvaifler, 1964; Peltier, Coste, and Delbarre, 1966) in synovial fluids from patients with rheumatoid arthritis which have been recently reported may be in some ways interrelated.

It has been assumed that at least some of the inclusions in the ragocytes could contain complexes composed of rheumatoid factor and gammaglobulins (Delbarre and others, 1966; Hollander and others, 1965; Zucker-Franklin, 1966). Before being phagocytosed, these complexes would possibly fix complement, and at the same time the opsonizing properties of complement would enhance phagocytosis of these complexes by polymorphonuclear cells.

Immunofluorescent detection of one of the $C^{\prime}$ components $\left(\mathrm{C}_{3}^{\prime}{ }_{3}\right)$ in the ragocyte inclusions has not proved possible in our laboratory, but an inversely proportional relationship was noted between haemolytic complement levels and ragocytes expressed in terms of their concentration in synovial fluid. This correlation was statistically significant $(P=0.05)$.

\section{Materials and Method}

Synovial fluid samples collected by aspiration from the knee joint in 73 cases were immediately poured into sterilized $50-\mathrm{ml}$. bottles containing glass beads, and defibrination was performed by gentle agitation for 5 minutes. The fluid was spun down at 3,000 r.p.m. for 10 minutes in a cold centrifuge.

One drop of the sediment was placed on a clean glass microscopic slide and covered with a $22 \times 22 \mathrm{~mm}$. cover-slip sealed with paraffin. The ragocytes were counted directly without staining using an immersion microscope $(\times 1,200)$, and their number was expressed

*Address: 27 rue du Faubourg St. Jacques, Paris XIV, France. as a percentage of the total number of white cells in the sample.

The supernate was centrifuged at 10,000 r.p.m. for 20 minutes at $4^{\circ} \mathrm{C}$. The haemolytic complement was measured immediately or after a few days' storage in a deep freeze at $-30^{\circ} \mathrm{C}$. The details of this method have been described elsewhere (Peltier and others, 1966). By this technique the values were found to vary between 35 and $50 \mathrm{C}^{\prime} \mathrm{H}_{50}$ units $/ \mathrm{ml}$. (mean 42.5 ) in normal human serum, between 0 and $30 \mathrm{C}^{\prime} \mathrm{H}_{50}$ units $/ \mathrm{ml}$. in synovial fluids from patients with rheumatoid arthritis, and between 25 and $100 \mathrm{C}^{\prime} \mathrm{H}_{50}$ units $/ \mathrm{ml}$. in synovial fluids from those with other types of joint inflammatio (gout, Reiter's syndrome, infective arthritis, etc.).

\section{Results}

The haemolytic complement level and ragocyte concentration were studied simultaneously in synovial fluid samples from 73 patients, in 55 of whom the diagnosis was firmly established (Table, opposite).

Of the 55 patients, 24 had rheumatoid arthritis (15 sero-positive and 9 sero-negative). The haemolytic complement levels ranged from 0 to $28 \cdot 5$ $\mathrm{C}^{\prime} \mathrm{H}_{50}$ units $/ \mathrm{ml}$. and the ragocyte concentrations from 7 to 45 per cent. in this group. In one rheumatoid patient with clinical features suggesting a diagnosis of systemic lupus erythematosus the complement level was $4 \cdot 17 \mathrm{C}^{\prime} \mathrm{H}_{50}$ units $/ \mathrm{ml}$. and the ragocyte concentration 80 per cent.

In twelve patients with Reiter's syndrome, the haemolytic complement levels ranged from 30.6 을 to $95 \mathrm{C}^{\prime} \mathrm{H}_{50}$ units $/ \mathrm{ml}$. and the ragocyte concentra- N tions from 0 to 25 per cent., but two cases observed 0 during an inactive stage of the disease had relatively $N$ low complement levels $\left(10 \cdot 2\right.$ and $12 \cdot 5 \mathrm{C}^{\prime} \mathrm{H}_{50}$ units/ N $\mathrm{ml}$.) with ragocyte concentrations of 20 and 7 per $\underset{2}{\sigma}$ cent. respectively.

In eighteen cases, a definite diagnosis could not $\stackrel{0}{\overparen{D}}$ be established: these included six cases of possible $\stackrel{\mathscr{D}}{\rightarrow}$ rheumatoid arthritis and twelve of unclassified 0 inflammatory polyarticular arthritis. 
TABLE

HAEMOLYTIC COMPLEMENT LEVEL AND RAGOCYTE CONCENTRATION IN 73 SYNOVIAL FLUIDS

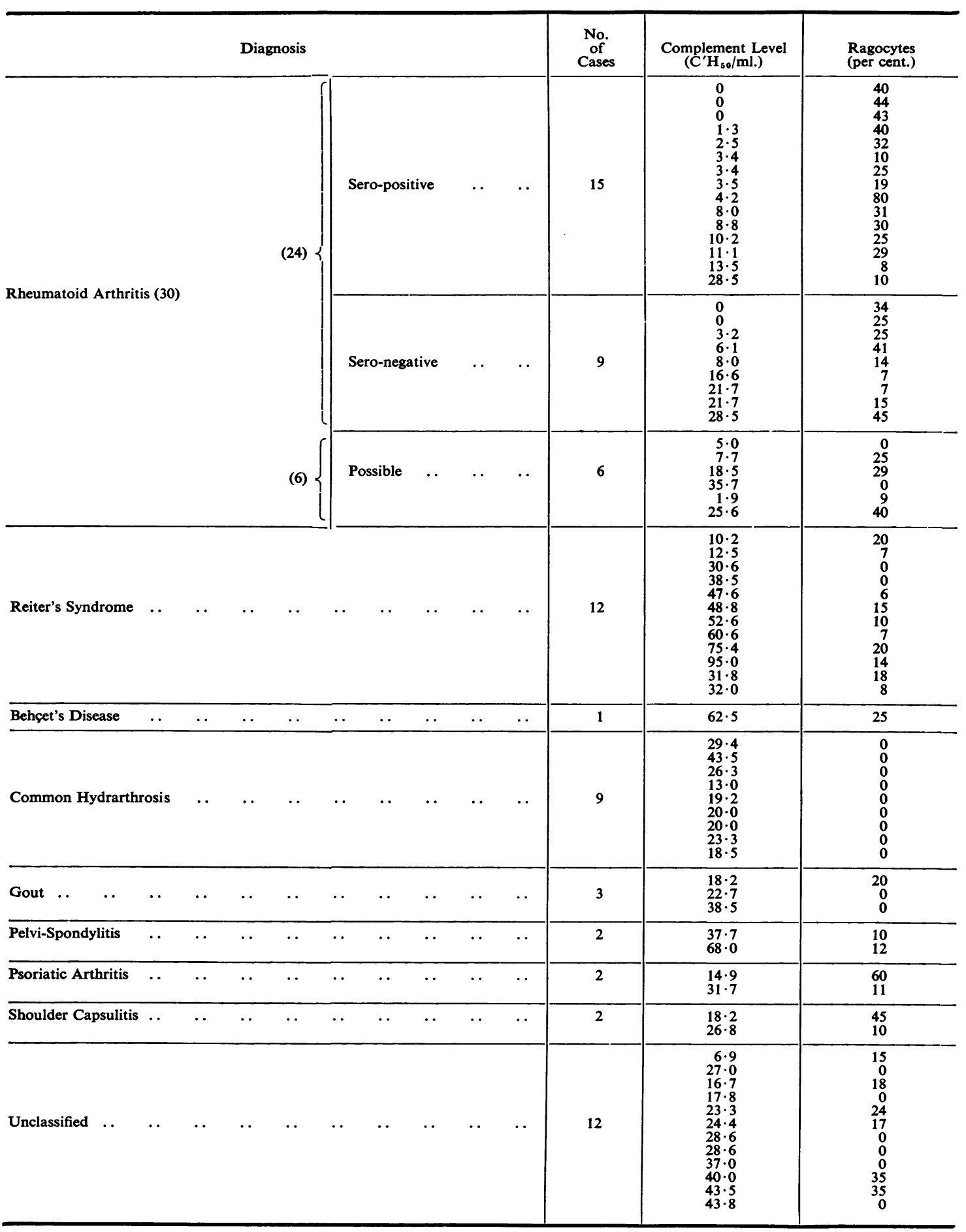


The correlation between decreasing haemolytic complement levels and increasing ragocyte concentrations (Figure) is statistically significant when all the 73 synovial fluid samples examined are computed $(P=0.05)$. This correlation is even more significant $(\mathrm{P}<0.01)$ when only those fluids containing $20 \mathrm{C}^{\prime} \mathrm{H}_{50}$ units $/ \mathrm{ml}$. complement or less are considered; this category includes most of the cases of rheumatoid arthritis, There was no significant difference between the sero-positive and seronegative rheumatoid cases, nor did those with Reiter's syndrome show any characteristic features.

\section{Discussion}

This inverse correlation between haemolytic complement levels and ragocyte concentrations may indicate that the complement has a part to play in ragocyte formation. Ragocyte granules are generally considered to be pinocytotic vacuoles which have already fused with lysozome elements to form phagosome granules; even if they have an heterogeneous content (Zucker-Franklin, 1966), it has now been shown that at least some of them contain IgM, and less frequently, IgG (Delbarre and others, 1966; Hollander and others, 1965; Zucker-Franklin, 1966). IgM and IgG could be present as "Rheumatoid Factor + IgG complexes", formed in the synovial fluid before their phagocytosis by polymorphonuclear cells. On the other hand it is known that, in order to react with rheumatoid factor and to combine with it, the IgG have to undergo structural modifications; these may be produced by aggregation (e.g. heat-aggregation) (Christian, 1958) or by the union of an antibody-IgG with its specific antigenic substrate (Vaughan, 1956). The latter process would be the one most probably involved in rheumatoid arthritic synovitis, but the nature of the responsible antigen can not yet be conjectured (Delbarre and Peltier, 1967). It is $c$ apparent that the type of modifications that makes $\vec{O}$ the IgG react with the rheumatoid factor also makes $\overrightarrow{\mid}$ them capable of fixing complement, so that one of $\omega_{\sigma}$ the pathological effects of rheumatoid arthritis would be the intra-synovial formation of antigen- ? antibody (IgG) complexes leading to the fixation $\mathcal{N}$ of complement and (if available as in sero-positive rheumatoid arthritis) of rheumatoid factor.

The fate of these complexes could be to form a deposit within the synovial membrane (Fish, 근 Michael, Gewurz, and Good, 1966; Rodnam, $z$ Williams, Bilka, and Müller-Eberhard, 1964) or to undergo phagocytosis by polymorphonuclear cells. This phagocytosis would, in turn, be considerably increased by the opsonizing power of complement, a property which has been clearly proved $\overrightarrow{0}$ vitro (Nelson, personal communication), as well $\stackrel{9}{\mathrm{~g}}$ in vivo (Rowley, Thoni, and Isliker, 1965).

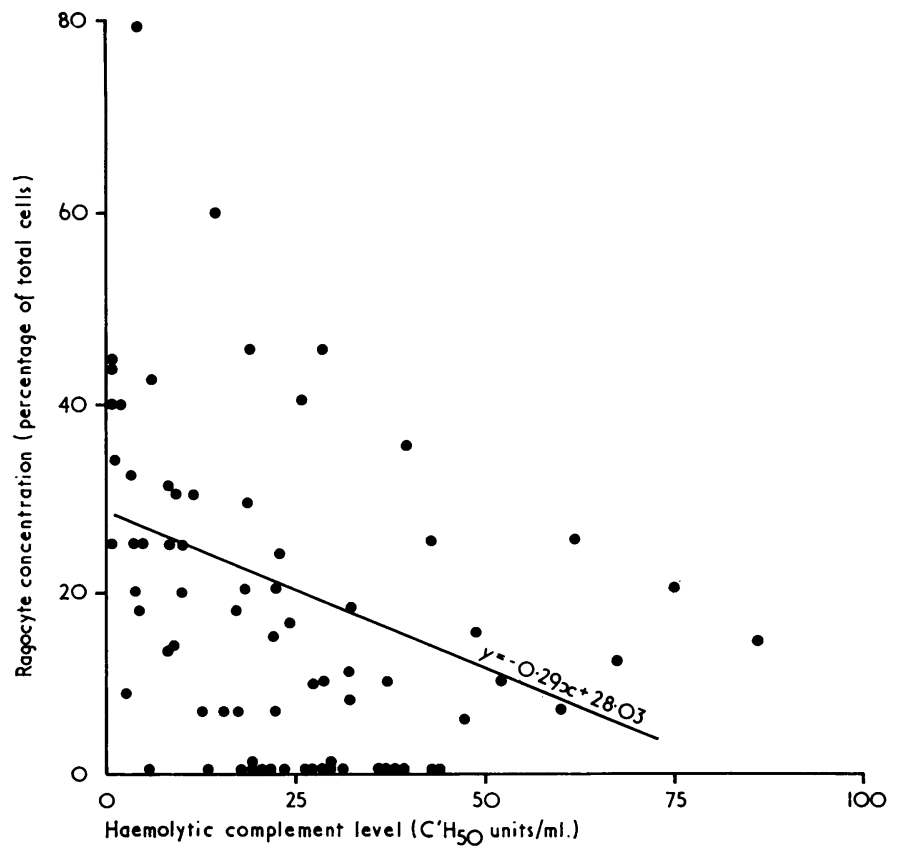

Figure.-Correlation between haemolytic complement levels and ragocyte concentrations in 73 synovial fluids: each point represents one synovial fluid $(P=0.05)$. 


\section{Summary}

An inverse and statistically significant $(P=0.05)$ correlation has been demonstrated between the haemolytic complement level and the ragocyte
( $R$ A cell) concentration in synovial fluids from patients with a variety of joint disorders. The mean correlations is even more significant $(P<0.01)$ in fluids from patients known to suffer from rheumatoid arthritis.

\section{REFERENCES}

Christian, C. L. (1958). J. exp. Med., 108, 139 (Characterization of the "reactant" (gamma globulin factor) in the FII precipitin reaction and the FII tanned sheep cell agglutination test).

Delbarre, F., Kahan, A., Amor, B., and Krassinine, G. (1966). Path. et Biol., 14, 796 (Étude clinique et expérimentale de la ragocytose synoviale: interêt pour le diagnostic et l'étude pathogénique des rhumatismes inflammatoires).

_ and Peltier, A. (1967). Bull. Soc. méd. Hôp. Paris, 117, 1255 (Les perturbations immunologiques au cours de la polyarthrite rhumatoïde: leur place dans la pathogénie de l'inflammation synoviale).

Fish, A. J., Michael, A. F., Gewurz, H., and Good, R. A. (1966). Arthr. and Rheum., 9, 267 (Immunopathologic changes in rheumatoid arthritis synovium).

Hedberg, H. (1963). Acta rheum. scand., 9, 165 (Studies on the depressed hemolytic complement activity of synovial fluid in adult rheumatoid arthritis).

- (1964). Ibid., 10, 109 (The depressed synovial complement activity in adult and juvenile rheumatoid arthritis).

Hollander, J. L., McCarty, D. J., Astorga, G., and Castro-Murillo, E. (1965). Ann. intern. Med., 62, 271 (Studies on the pathogenesis of rheumatoid joint inflammation I. The "R.A. cell" and a working hypothesis).

Nelson, R. A., Jr. (in press). "The Role of Complement in Immune Phenomenon". Proposed chapter No. 9, vol. 2, "The Inflammatory Process".

Pekin, J. T., and Zvaifler, N. J. (1964). J. clin. Invest., 43, 1372 (Hemolytic complement in synovial fluid).

Peltier, A., Coste, F., and Delbarre, F. (1966). Presse méd., 74, 1523 (Études sur le complément hémolytique dans certaines maladies ostéo-articulaires).

Rodnam, W. W., Williams, R. C., Bilka, F. J., and Müller-Eberhard, H. J. (1964). Arthr. and Rheum., 7, 749 (abstract) (Immunofluorescent localization of Beta $1-\mathrm{C}$ and Beta 1 -E globulin complement components in synovial tissues from rheumatoid arthritis patients).

Rowley, D., Thöni, M., and Isliker, H. (1965). Nature (Lond.), 207, 210 (Opsonic requirements for bacterial phagocytosis).

Vaughan, J. H. (1956). J. Immunol., 77, 181 (Behavior of the rheumatoid arthritis agglutinating factor with immune precipitates).

Zucker-Franklin, D. (1966). Arthr. and Rheum., 9, 24 (The phagosomes in rheumatoid synovial fluid leukocytes: a light, fluorescence, and electron microscope study).

Le taux de complément hémolytique et la concentration de ragocytes dans le liquide synovial

\section{RÉSUMÉ}

Une corrélation inverse et statistiquement significative $(P=0,05)$ a été démontrée entre le taux de complément hémolytique et la concentration de ragocytes dans le liquide synovial d'une série de 73 malades atteints de différents types d'affections arthritiques. Cette corrélation est encore plus significative $(P<0,01)$ dans les liquides provenant de malades atteints de polyarthrite rhumatoïde.
Las cifras del complemento hemolítico y la concentración de ragocitos en el líquido sinovial

\section{SUMARIO}

Se comprobó la existencia de una correlación inversa y estadistícamente significativa $(P=0,05)$ entre las cifras del complemento hemolítico y la concentración de ragocitos en el líquido sinovial de una serie de 73 enfermos con diferentes tipos de afección artrítica. Esta correlación es aún más significativa $(P<0,01)$ en líquidos de enfermos con artritis reumatoide. 